\title{
Explicit Study of Epoxy/ Momordica Angustisepala Fiber and Rice Husk Ash Nanoparticle Composites for Roofing Sheet Application
}

\author{
Nwoji Clifford Ugochukwu ${ }^{1}$, Aigbodion Victor Sunday ${ }^{2,3,4 *}$, Adams Mohammed Sani ${ }^{2,5}$, Obetta Emmanuel Chinonso ${ }^{5}$ \\ ${ }^{1}$ Department of Civil Engineering, University of Nigeria, Nsukka 410001, Nigeria \\ ${ }^{2}$ Department of Metallurgical and Materials Engineering, University of Nigeria, Nsukka 410001, Nigeria \\ ${ }^{3}$ Africa Centre of Excellence, ACESPED University of Nigeria, Nsukka 410001, Nigeria \\ ${ }^{4}$ Faculty of Engineering and the Built Environment, University of Johannesburg, P. O. Box 534, Auckland Park, South Africa \\ ${ }^{5}$ Department of Metallurgical and Materials Engineering, Airforce Institute of Technology, Kaduna 800282, Nigeria \\ ${ }^{6}$ African University of Science and Technology, Abuja, P.M.B 681 Garki, Nigeria
}

Corresponding Author Email: victor.aigbodion@unn.edu.ng

https://doi.org/10.18280/acsm.440601

Received: 6 August 2020

Accepted: 8 December 2020

\section{Keywords:}

stress analysis, momordica angustisepala fiber, rice husk ash nanoparticle, roofing sheets

\begin{abstract}
The development of roofing sheets using sustainable materials to reduce the health hazard pose by asbestos, corrosion of galvanized zinc, and cost of long span aluminum has been giving attention. In this work, density, tensile properties, corrosion resistance and stress analysis of Momordica angustisepala fiber (MAf) and rice husk ash nanoparticle/epoxy composite was used as criteria to determine the suitability of the new material as a roofing sheet application. Roofing sheets of lower weight can be produced with this developed material. The yield strength and tensile strength of 73.45 and $75.12 \mathrm{MPa}$ are within the strength recommended for galvanized zinc and long span aluminum. The new material can be used in the production of roofing sheets with better corrosion resistance than galvanized zinc and long span aluminum. It was established that light weight roofing sheets with better corrosion resistance can be made with this composite.
\end{abstract}

\section{INTRODUCTION}

In recent years there was the emphasis to produced roofing sheets in the building and construction industry using composites materials reinforced with sustainable materials such as industrial and agricultural wastes [1,2]. The use of industrial and agricultural wastes in the production of high strength and lightweight roofing sheets can reduce the cost of building and construction since the cost of roof sheets constitute up to $8 \%$ of the overall cost of building $[3,4]$. Galvanized zinc, asbestos, and aluminum long span were the major materials in the building and construction $[5,6]$. However, despite the properties of these materials in the building industry, each material has its merit and demerit. Asbestos sheets, for example, is pose to health hazard and effort has been made by the world health organization to effect the ban on the use of asbestos in the building industry [7], Galvanized zinc is posed to corrosion after exposing of the roofing sheets to environmental condition, as a result of the reaction of the zinc with the environmental factors such as rainwater, seawater, and sunlight [8], aluminum long span could have been substituted to overcome the shortcoming of galvanized zinc and asbestos but the used of aluminum long span increases the overall cost of building which cannot be affordable in most developing countries of the world [9]. Hence there is the need to develop roofing sheets using industrial and agricultural wastes with good properties; ecofriendly and low cost become imperative. Since it has be reported by Akindapo et al. [10] reported on the production of roofing sheets using groundnut reinforced epoxy composites. Three particle sizes of $0.5,1$, and $1.5 \mathrm{~mm}$ were used in the production of the composites. They observed that the composites produced with the $0.5 \mathrm{~mm}$ particle size have the impact values of $29.65 \mathrm{KJ} / \mathrm{mm}^{2}$ with water absorption of $8.3 \%$. They concluded that the sample could be used in the production of roofing sheets. Molina et al. [11] presented stress analysis of corrugated sheets using the finite element method; five thickness sizes of roofing sheets were used in the analysis. The bending load of 2,500 N/m was used in the analysis. The numerical stress obtained agreed with the other scholars finding for corrugated sheets under the bending load. Based on the foregoing, this presence work will report for the first time the development of roofing sheet using the Maf and rice husk ash nanoparticle/epoxy composite, since there is little or no information on the production of roofing using the Maf and rice husk ash nanoparticle.

The significant of using the Maf and rice husk in the production of roofing sheets will lower the cost of roofing sheets, ecofriendly, reduced the environmental pollution and better corrosion resistance, since it has been reported [12] that Rice husk is one of the agro-waste that is causing environmental pollution worldwide. A large quantity of the rice husk is been disposed to open burning in my Africa countries and effort has been made to converted this waste for the use of mankind. Fernandes et al. [13] has revealed that rice husk contains carbon, silica, calcium, magnesium, iron, and has been used in the production of composites materials, glass, and soil stabilization.

Maf is one of the promising natural fibers for the production of polymer composites [14]. The fibers can be obtained in many Africa countries such as Nigeria, Cameroon, Ghana, Benin, and Cote Divoire etc. [15]. The fibers are obtained from 
MA stem by pounding and washing of the fibers to remove impurities [16]. It can be cultivated in commercial quantities. The MA fibers are used in Africa as a local sponge for bathing [14]. Achigan-Dako [16] used MA as local medicine in Nigeria and Atuanya et al. [14] characterized the MAf for possible use for polymer composites production. Their findings show tensile strength of 35-57.93 $\mathrm{MPa}$ and tensile modulus 2-4.4 GPa.

\section{MATERIALS AND METHOD}

\subsection{Preparation of the rice husk nanoparticles}

The sol-gel method of production of nanoparticle which is one of the inexpensive methods of producing nanoparticle was employed in this research. The sol-gel method is based on the chemical reaction. The sol-gel method was used in the production of rice husk ash nanoparticle (RHAnp). Sodium hydroxide solution was added to the rice husk ash, the mixture was covered in Erlenmeyer flask and stir for two hours. The solution was then filtered and the carbon residue was removed. The filtrate was cooled to room temperature and the $\mathrm{HCl}$ was added and stir until $\mathrm{pH}$ of 7 and aging was done at $65^{\circ} \mathrm{C}$ for 8 hours to obtain gel. A similar method of production of nanoparticle was reported by Ezema et al. [17].

The transmission electron microscope model (JEOL JSM840A) was used to determine the particles of the rice husk ash nanoparticle. The rice husk ash nanoparticle sample was prepared by dispersing the rice husk ash nanoparticle in acetone by sonication and was drip on copper grid coated with carbon film.

\subsection{Preparation of the momordica angustisepala fiber (MAf)}

MAf (Figure 1) was cleaned using acetone and oven-dried at a temperature of $65^{\circ} \mathrm{C}$ for $7 \mathrm{hrs}$. The cleaned MAf was immersed in $75 \mathrm{ml}$ of $\mathrm{NaOH}$ for $4 \mathrm{hrs}$. and cleaned with a $5 \%$ $\mathrm{HCl}$ solution. The functionalization of the MAf was done using Aminopropyltriethoxysilane (APS) in 100ml ethanol. The microscopic study of the MAf was determined by the JEOL JSM840A.

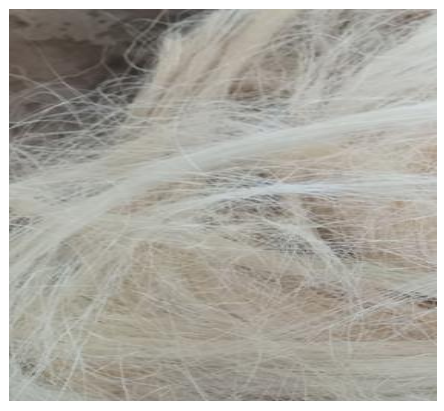

Figure 1. Photograph of MAf

\subsection{Production of the composites}

A white Epoxy resin LY556 (HERENBA BRAND) and Hardener (HY951) was used in the production of the composites. The hand-laying method was used in the production of the Epoxy-10wt\% MAf-5wt\% RHAnp hybrid composites. Before the production the $10 \mathrm{wt} \%$ MAf was matted and cut, weighted and placed into wooden mold covered with aluminium foils. The epoxy was mix thoroughly with the $5 \mathrm{wt} \%$ RHAnp. Magnetic stirrer of speed $250 \mathrm{rpm}$ was used to stir the mixture to obtained homogenous mixture. The hardener (HY951) was then added to the mixture and was stir again before pouring in the matted fibre mould. During the production roller of $40 \mathrm{~mm}$ diameter was used to remove air trapped inside the mould. The composite was cured inside the mould for twenty-four (24) hours and then the samples were removed from the mould (Figure 2).

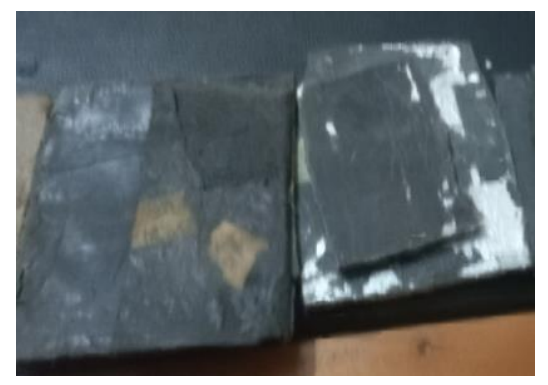

Figure 2. Photograph of the composite sample

The tensile properties and corrosion test were used in this research to determine the suitability of this developed composite as roofing sheet. The tensile test was performed in the Testometric testing machine and results are analyzed to calculate the tensile strength of samples per ASTM D3039, SEM model JEOL JSM840A was used to determine the microstructure of the composite. Corrosion resistance is very importance properties of roofing sheets. The corrosion test samples were cut from galvanic zinc, asbestos, and long span aluminum and the developed composite. The electrochemical analysis was done using the corrosion tester model: CHI604E. The test was done at $0.0012 \mathrm{~V} \mathrm{~s}^{-1}$ and potential $-1.5 \mathrm{~V}$ to $1.5 \mathrm{~V}$ as per the ASTM G19 Standard in simulated seawater $(3.5 \%$ $\mathrm{NaCl}$ ). Eq. (1) was used in computing the polarization resistance.

$$
R_{P}=\frac{\beta_{a} \beta_{c}}{2.3 \operatorname{icorr}\left(\beta_{a}+\beta_{c}\right)}
$$

where, $\beta_{\mathrm{a}}$ is the Tafel anodic constant, $\beta \mathrm{c}$ the cathodic Tafel constant and current density (color).

\section{RESULTS AND DISCUSSION}

\subsection{TEM microstructure}

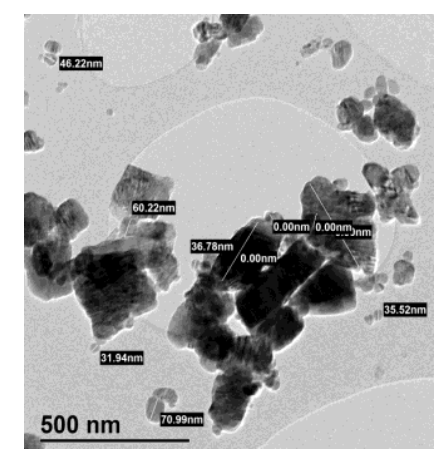

Figure 3. TEM image of the rice husk ash nanoparticle 
The TEM image of the sample under investigation is displayed in Figure 3. The TEM image shows uniform fine particles randomly distributed was achieved in Figure 3, particle cluster, and agglomeration of particles was not seen. Average particles of 31.94-70.99 nm (Figure 3) were obtained.

\subsection{Microstructure of MAf}

Figures 4 displayed the SEM/EDS of the untreated and treated MAf. The MA fibers are straight and longitudinal in shapes as evidence in the SEM image in Figure 3. In Figure 4b cleaned and straight fibers without grooves were obtained after treatment of the fibers. These could be attributed to the fact that the chemical treatment helps to remove the waxy epidermal tissue, hemicelluloses in the MAf. The reason for the chemical treatment of the MAf is to enhanced the interfacial bonding between the fibres and the epoxy polymer. Similar observation was obtained in the work $[18,19]$.

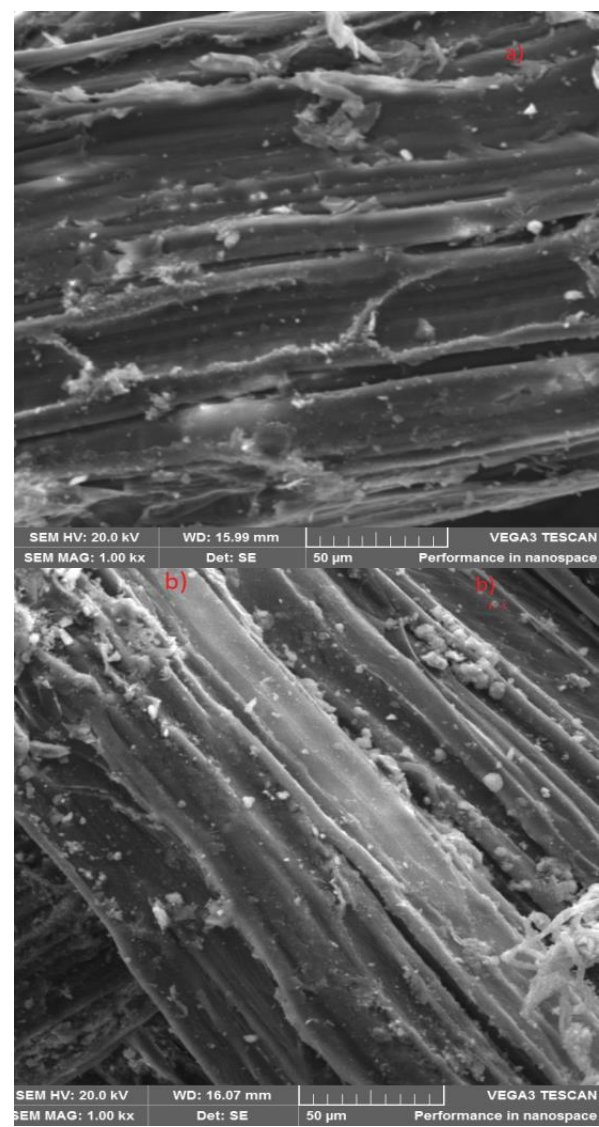

Figure 4. a) Untreated Maf; b) Treated Maf

\subsection{Density}

The density of the developed composite is $1.17 \mathrm{~g} / \mathrm{cm}^{3}$. The values are lower that the density of $1.26-1.51 \mathrm{~g} / \mathrm{cm}^{3}, 2.45-2.6$ $\mathrm{g} / \mathrm{cm}^{3}$ and $7.8 \mathrm{~g} / \mathrm{cm}^{3}$ for long span aluminum, asbestos and galvanized steel sheets respectively (Table 1). That mean lower weight roofing sheets can be produced with this new material.

\subsection{Tensile strength and fracture microstructure}

Figure 5 displayed the stress/strain and tensile fracture surface of the developed composite. In Figure 4a it was seen clearly that the sample has a large area under the stress/ strain graph this was responsible for the high values of energy to break of $89.08 \mathrm{~N} / \mathrm{m}$ and strain at break of $45.27 \%$. Elastic modulus of $3.62634 \mathrm{GPa}$, yield strength, and tensile strength of 73.45 and $75.12 \mathrm{MPa}$ were obtained. The high elastic modulus and tensile strength obtained means that the reinforcing phases were able to increase the stiffness of the materials, strength, energy to break, and percentage elongation. The increase in the strength of the composites could be attributed to good interfacial bonding between the RHAnp, MAf and epoxy matrix which help to transfer of load from the reinforcing phases to the matrix and blocking the interlocking molecular chains of the polymer and reduced the ease mobility of the polymer chains under load. This value of the strength obtained in this work is high enough for the roofing sheets application. This is in par with the other materials used in roofing sheets application (Table 1 ).

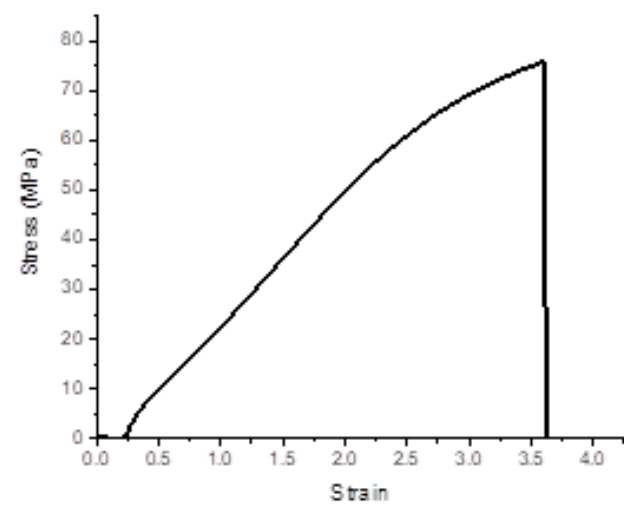

Figure 5. Variation of stress with strain

Table 1. Properties of roofing sheets of thickness of $4 \mathrm{~mm}$

\begin{tabular}{|c|c|c|c|c|}
\hline & $\begin{array}{c}\text { Tensile } \\
\text { strength } \\
(\mathrm{MPa})\end{array}$ & $\begin{array}{l}\text { Density } \\
\left(\mathrm{g} / \mathrm{cm}^{3}\right)\end{array}$ & $\begin{array}{c}\text { Elastic } \\
\text { Modulus } \\
(\text { Gpa) } \\
\end{array}$ & $\begin{array}{c}\text { Poissons } \\
\text { Ratio }\end{array}$ \\
\hline $\begin{array}{c}\text { ASTM E-466 } \\
\text { and NIS } 488 \\
\text { Long span } \\
\text { aluminium }\end{array}$ & $\begin{array}{l}28.00- \\
77.00\end{array}$ & $\begin{array}{l}1.26- \\
1.51\end{array}$ & 4.56 & 0.25 \\
\hline $\begin{array}{l}\text { ASTM C746- } \\
90(2014) \\
\text { Asbestos } \\
\text { sheets }\end{array}$ & $15-30.00$ & $\begin{array}{l}2.45- \\
2.60\end{array}$ & 0.95 & 0.34 \\
\hline $\begin{array}{c}\text { ASTM A525 } \\
\text { Galvanized } \\
\text { Steel }\end{array}$ & $55-105$ & 7.8 & $160-200$ & 0.29 \\
\hline $\begin{array}{l}\text { Developed } \\
\text { composite }\end{array}$ & 75.12 & 1.17 & 3.62634 & 0.3 \\
\hline
\end{tabular}

It was observed in Figure 6 that the fracture surface of the sample shows good interfacial bonding between the MAf, RHAnp, and the epoxy, particles pull out and crack were not observed, this was the major reason for the increment of strength in this work $[5,6]$.

The Tafel polarisation curves of the corrosion analysis of the roofing sheets in simulated sea environment using 3.5\% $\mathrm{NaCl}$ are displayed in Figure 7. It was observed that the potential of the samples obtained are $-0.38,-0.28,-0.15$ and $0.14 \mathrm{~V}$ for the galvanized zinc, long span aluminum, asbestos sheets and the developed composite respectively. The corrosion characteristics of the developed composite and asbestos are similar. The asbestos sheets and developed composite samples potential shifted to a higher potential than the galvanized zinc, long span aluminum. The quick reaction 
of the galvanized zinc sample at the initial period until the steady potential was attributed to the active reaction of zinc which serves as the sacrificial protection for the sheets. The mechanism of the corrosion of the galvanized zinc is the loss of electron of the zinc which later exposed the iron and increase the numbers of electron release from the anode to the cathode, hence increases the damage of the sample. This is the major problem faced using galvanized zinc sheets.

However, using long span aluminum have a better corrosion resistance than galvanized zinc but lower than that of the developed composite and asbestos. The developed composite and asbestos samples shifted to lower current density and higher corrosion potential as compared with the metallic samples. There was a wide range in the cathode and anode branch in the metallic samples which resulted to increase reaction of the samples with the medium. In case of the developed composite and asbestos samples the flow of electron does not occurred as a result of no moveable electron which lead to narrow ranges of cathode and anode branch observed in Figure 7. Corrosion rate of $2.8 \times 10^{3}, 0.9 \times 10^{3}$, $0.155 \times 10^{2}, 0.15 \times 10^{2}$ mil per year were obtained for galvanized zinc, long span aluminum, asbestos sheets and the developed composite respectively. This show that the corrosion problem of a metallic roofing sheets can be reduced using the developed composite.

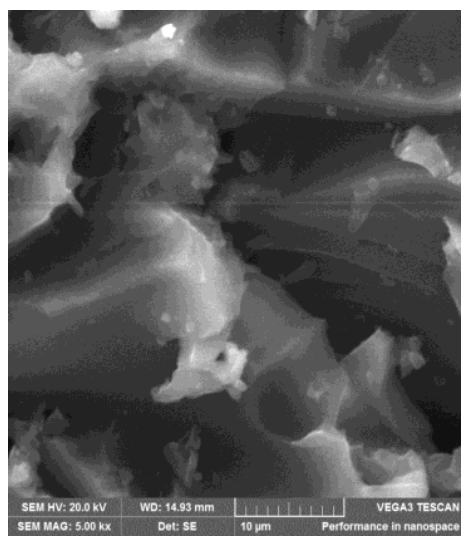

Figure 6. Fracture surface of the tensile sample

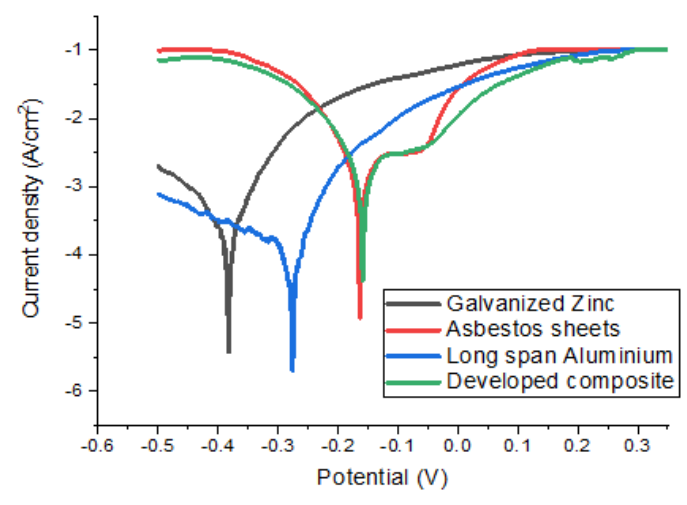

Figure 7. Tafel corrosion curves

\subsection{Autodesk simulation of the roofing sheets}

The mechanization of determining the stress analysis of roofing sheets is of great interest to the building and construction industry because it serves as a window for accepted or the rejection of roofing sheets during production. In this work, the simulation of the roofing sheets developed from rice husk ash nanoparticle and MAf was conducted using Autodesk software. The prototype of the roofing sheet used for the stress analysis is displayed in Figure 8. A compressive load of $100 \mathrm{~N}$ as per standard [3] was applied from the top of the roofing sheet (Figure 8). The material properties used for the analysis are displayed in Table 1.

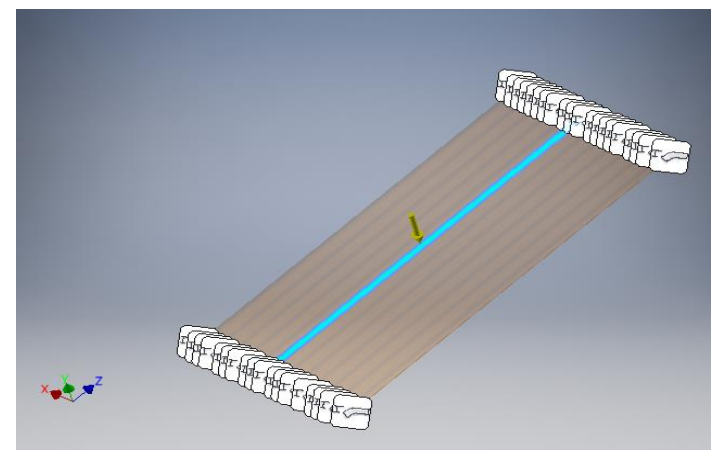

Figure 8. Developed composite roofing sheets under compressive stress

The boundary condition applied was the restraining of the displacement in $\mathrm{x}$ and $\mathrm{z}$ direction and support at the center location in y-displacement (Figure 8). For the meshing, the average element size of 0.1 fraction model diameter and 0.05 shells, $60^{\circ}$ maximum turning angle, 1.5 grading factor, and 0.2 minimum element sizes were used. The results of the stress analysis were displayed in Table 2 and all the plots obtained are shown in Figures 6-8. The von Misses stresses and strain are displayed in Figure 9, the values of the von Misses stress ranges from 0.0000787986 to $52.25 \mathrm{MPa}$. This was used to determine the yielding of the materials in question. The strain distribution and the displacement are measured in ( $\mathrm{mm})$ from the point where the forces were applied to the roofing sheets before failure or deformation occurred. Equivalent strain values of 0.0000000188355 to 0.0131786 ul were obtained.

The first principal and third principal stress values were obtained and displayed in Figure 10. It was observed that the values of the first principal stress range from -3.87916 to $40.0112 \mathrm{MPa}$, and that of the third principal stress from -41.913 MPa to 3.0379 MPa. Maximum displacement value of $83.4253 \mathrm{~mm}$ and factor of safety of 5.84281 and $15 \mathrm{ul}$ were obtained in this stress analysis of the composites roofing sheets (see Figure 10 and Table 2).

The linear structural analysis of the developed roofing sheets with sustainable materials shows Von stress of 52.25 MPa obtained in this study was attributed to the stiffness and strength obtained in this composite which is as a result of toughness obtained by the reinforcement that gives a minimum factor of safety of 2.18 (Figure 11). The value strength and factor of safety obtained are within the recommended standard for roofing sheets application $[1,2]$.

Table 2. Stress analysis of the simulation

\begin{tabular}{ccc}
\hline Name & Minimum & Maximum \\
\hline Volume & $415910 \mathrm{~mm}^{3}$ & \\
Displacement & $0 \mathrm{~mm}$ & $217.942 \mathrm{~mm}$ \\
Von Misses Stress & $0.0000530576 \mathrm{MPa}$ & $52.25 \mathrm{MPa}$ \\
1st Principal Stress & $-3.87916 \mathrm{MPa}$ & $59.718 \mathrm{MPa}$ \\
3rd Principal Stress & $-41.913 \mathrm{MPa}$ & $3.0379 \mathrm{MPa}$ \\
Safety Factor & $2.18 \mathrm{ul}$ & $15 \mathrm{ul}$ \\
Equivalent Strain & $0.0000000188355 \mathrm{ul}$ & $0.0131786 \mathrm{ul}$ \\
\hline
\end{tabular}




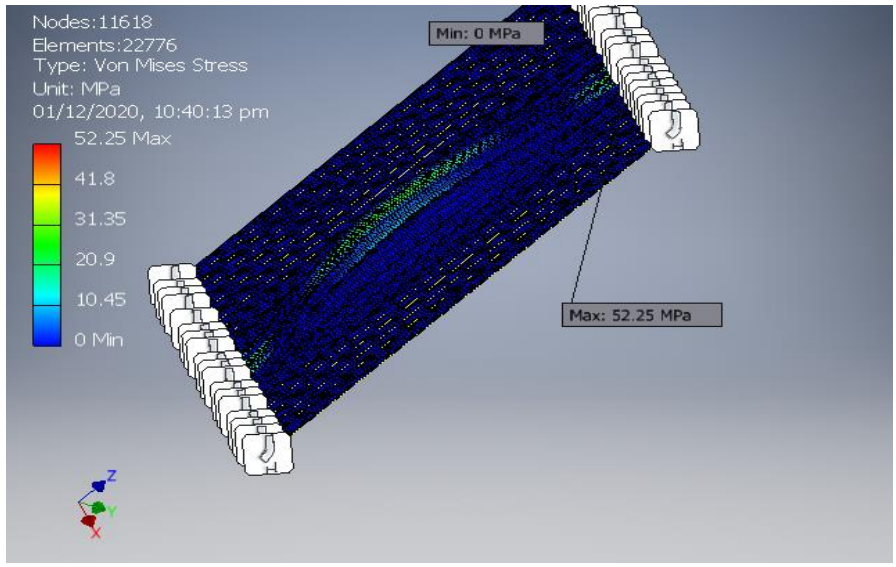

(a)

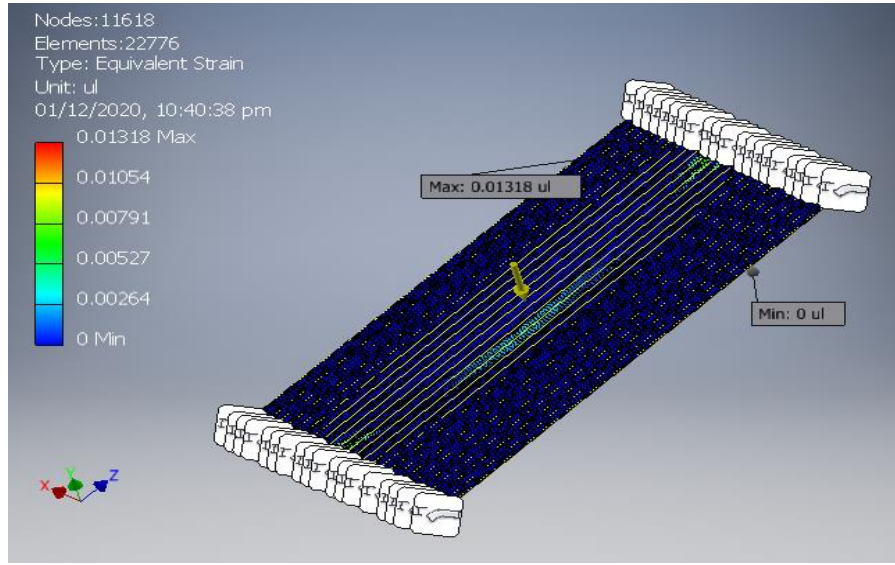

(b)

Figure 9. (a) Von Misses stress (b) Equivalent Strain

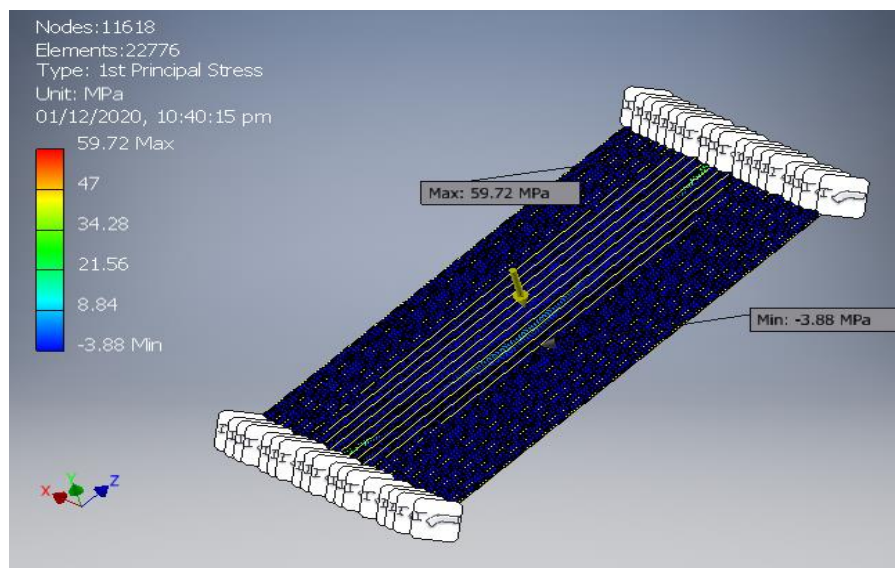

(a)

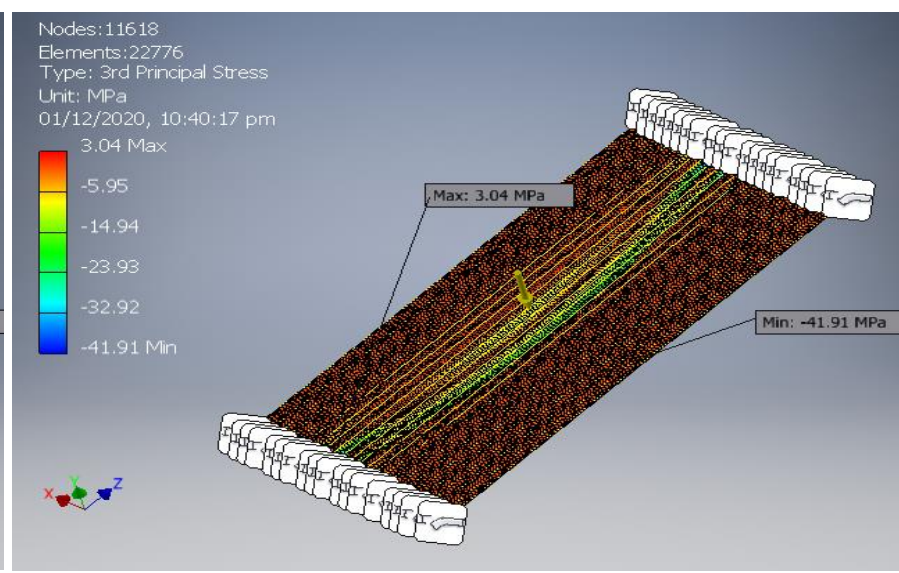

(b)

Figure 10. (a) The first principal stress (b) The third principal stress

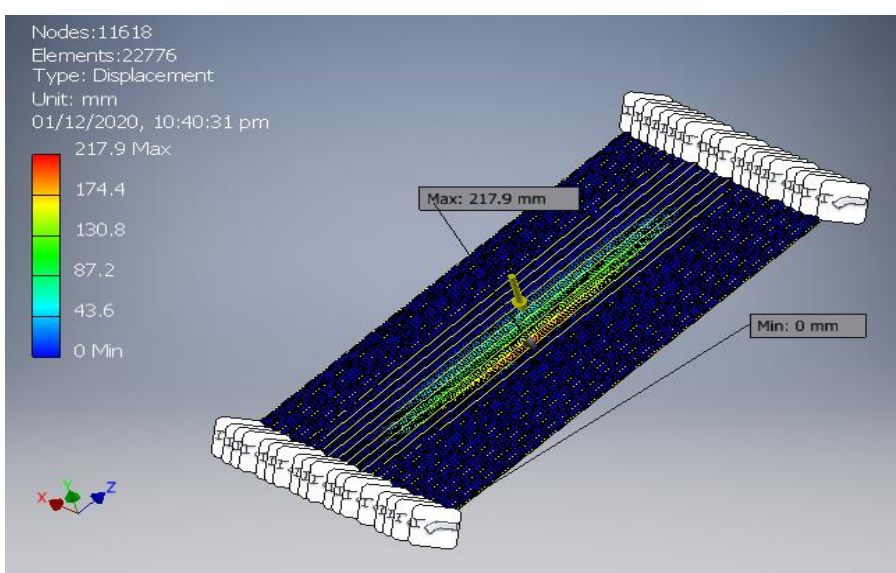

(a)

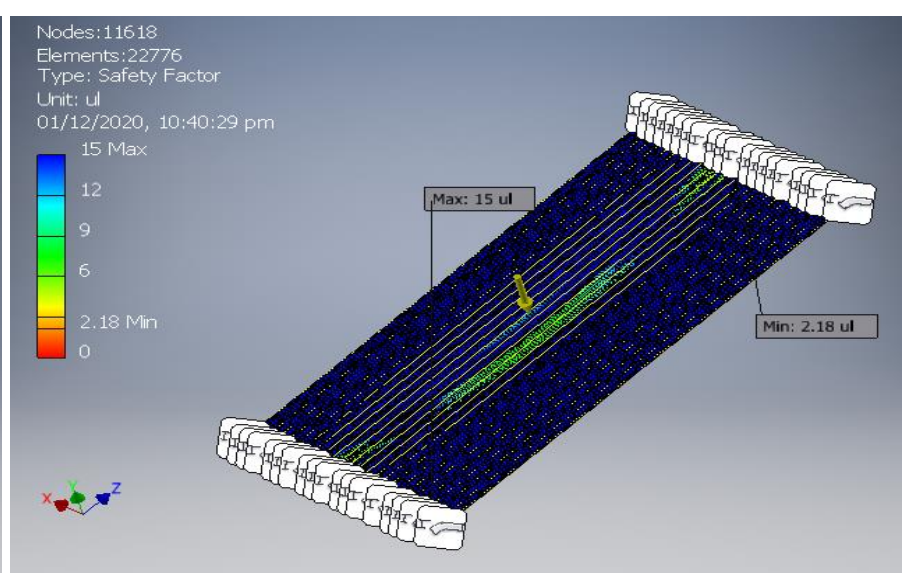

(b)

Figure 11. (a) Displacement (b) Factor of safety

\section{CONCLUSIONS}

From discussion on the development of roofing sheets using epoxy-MAf and RHAnp materials the following new findings are made:

1) Roofing sheets of lower weight can be produced with this developed material.

2) The yield strength and tensile strength of 73.45 and 75.12 $\mathrm{MPa}$ are within the strength recommended for galvanized zinc and long span aluminum.

3) The new material can be used in the production of roofing sheets with better corrosion resistance than galvanized zinc and long span aluminum.

4) The fracture surface of the sample shows good interfacial bonding between the MAf, RHAnp and the epoxy.

5) The linear structural analysis of the developed roofing sheets with sustainable materials shows Von stress of 
56.54 $\mathrm{MPa}$ which is lower than the maximum stress in the materials.

6) The value strength and factor of safety obtained are within the recommended standard for roofing sheets application.

7) It was established that light weight roofing sheets with better corrosion resistance can be made with this composite.

\section{ACKNOWLEDGEMENT}

The author hereby appreciates and acknowledge the Africa Centre of Excellence for Sustainable Power and Energy Development, ACE-SPED, University of Nigeria, Nsukka, Faculty of Engineering and Built Environment, University of Johannesburg, Auckland Park, South Africa for their support.

\section{REFRENCES}

[1] Olorunnisola, A.O. (2018). Development of sustainable building materials from agro-industrial wastes in Nigeria. IntehOpen. http://dx.doi.org/10.5772/intechopen.81662

[2] Odera, R.S., Onukwuli1, O.D., Atuanya, C.U. (2015). Characterization of the thermo-microstructural analysis of Raffia palm fibers proposed for roofing sheet production. Journal of Minerals and Materials Characterization and Engineering, 3(4): 335-343. https://doi.org/10.4236/jmmce.2015.34036

[3] Alade, G.A., Olutoge, F.A. (2004). Bamboo fiberreinforced cement used as a roofing sheet. Journal of Civil Engineering Research and Practice, 1(2): 107-118. https://doi.org/10.4314/jcerp.v1i2.29132

[4] Kolawole, F.O., Adeniji, S.A., Idowu, A.T., Owoseni, T.O., Ngasoh, O.F., Soboyejo, W.O. (2014). Corrugated laterite based ceramic roof tile stabilized with cement. International Journal of Engineering and Technology, 4(3): 145-149.

[5] Prusty, J.K., Patro, S.K., Basarkar, S.S. (2016). Concrete using agro-waste as fine aggregate for the sustainable built environment - a review. International Journal of Sustainable Built Environment, 5(2): 312-333. https://doi.org/10.1016/j.ijsbe.2016.06.003

[6] SathishKumar, P., Neethimanickam, I., Swikker, R.R.J., Maheswari, K.S. (2020). Strength and behavior analysis of honey comb sandwich composite structure. International Journal of Scientific \& Technology Research, 9(1): 2668.

[7] Ezenwa, O.N., Obika, E.N., Umembamalu, C., Nwoye, F.C. (2019). Development of ceiling board using breadfruit seed coat and recycled low-density polyethylene. Heliyon, 5(11): E02712. https://doi.org/10.1016/j.heliyon.2019.e02712

[8] Ramezanzadeh, B., Arman, S.Y., Mehdipour, M. (2014). Anticorrosion properties of an epoxy zinc-rich composite coating reinforced with zinc, aluminum, and iron oxide pigments. Journal of Coatings Technology and Research, 11: 727-737. https://doi.org/10.1007/s11998-014-9580-0

[9] Aigbodion, V.S. (2012). Development of Al-Si-Fe/Rice husk ash particulate composites synthesis by double stir casting method. Usak University Journal of Material Sciences, 2: 187-197.

[10] Akindapo, J.O., Binni, U.A., Sanusi, O.M. (2015). Development of roofing sheet material using groundnut shell particles and epoxy resin as composite material. American Journal of Engineering Research, 4(6): 165173.

[11] Molina, J.C., Fiorellib, J., Savastano, H. (2014). Analysis of the stresses in corrugated sheets under bending. Materials Research, 17(2): 338-345. https://doi.org/10.1590/S1516-14392014005000003

[12] Suwanprateeb, J., Hatthapanit, K. (2002). Rice-husk-ashbased silica as a filler for embedding composites in electronic devices. Journal of Applied Polymer Science, 86(12): 3013-3020. https://doi.org/10.1002/app.11291

[13] Fernandes, I.J., Santos, R.V., Araujo dos Santos, E.C., Campos Rocha, T.L.A., Domingues Junior, N.S., Mendes Moraes, C.A. (2018). Replacement of commercial silica by rice husk ash in epoxy composites: A comparative analysis. Materials Research, 21(3): 20160562. https://doi.org/10.1590/1980-5373-mr-20160562

[14] Atuanya, C.U., Ebunoha, E.O., Isaac, G.O., Aigbodion, V.S. (2012). Characterization of the thermo-mechanical behavior of Momordica angustisepala fiber intended for the manufacturing of polymer composites. Pacific Journal of Science and Technology, 14: 40-47.

[15] Ede, A.N., Olofinnade, O.M., Ugwu, E.I., Salau, A.O. (2018). Potentials of Momordica angustisepala fiber in enhancing strengths of normal Portland cement concrete. Cogent Engineering, 5(1): 1431353. https://doi.org/10.1080/23311916.2018.1431353

[16] Achigan-Dako, E.G. (2012). Momordica angustisepala harms. In M. Brink \& E. G. Achigan-Dako (eds.), Prota 16: Fibres/Plantes à fibers. [CD-Rom], p. 334. Wageningen: PROTA.

[17] Ezema, I.C., Aigbodion, V.S., Okonkwo, E.G., Obayi, C.S. (2020). Fatigue properties of value-added composite from Al-Si-Mg/palm kernel shell ash nanoparticles. The International Journal of Advanced Manufacturing Technology, 107: 3247-3257. https://doi.org/10.1007/s00170-020-05268-z

[18] Aigbodion, V.S., Edokpia, R.O., Asuke, F., Eke, M.N. (2018). Development of egg shell powder solution as ecofriendly reagent: for chemical treatment of natural fibers for polymer composites production. Journal of Materials and Environmental Sciences, 9(2): 559-564. https://doi.org/10.26872/jmes.2018.9.2.61

[19] Odera, R.S., Onukwuli, O.D., Aigbodion, V.S. (2019). Effect of alkali-silane chemical treatment on the tensile properties of raffia palm fiber. Australian Journal of Multi-Disciplinary Engineering, 15(1): 91-99. https://doi.org/10.1080/14488388.2019.1648961 